\title{
Detection of Human Papilloma Virus type 6 and type 11 in women with Breast Cancer by in situ hybridization technique.
}

\author{
Noor H. Ismail * \\ Ahmed M. Al-Shammeri ** \\ Ayser H. Latif *** \\ Ayeda M. Majeed * \\ Dina W. Abed *
}

\author{
MSc \\ PhD \\ FICMS(path) \\ BSc \\ BSc
}

\begin{abstract}
:
Background: Breast cancer is one of the common malignancies among women worldwide. Human papillomavirus (HPV) infections have been linked to many human cancers in addition to cervical cancer and one of them is breast cancer.

J Fac Med Baghdad

2015; Vol.57, No.1

Received Sept.2014

Accepted Fab.2015

Objective: To investigate the presence of human papilloma virus type 6 and type 11 in breast cancer tissue specimens by in situ hybridization technique.

Patients and Methods: Thirty four formalin-fixed, paraffin embedded tissue blocks from breast cancer patients were obtained from the archives of the pathology laboratory of Al-Yarmouk Teaching Hospital from January 2011 to July 2012. In addition formalin-fixed, paraffin embedded blocks tissue for twenty fibroadenoma of breast were collected and used as control group. In situ hybridization technique was used for the molecular detection of HPV type 6 and HPV type 11.

Results: There were $82.4 \%$ of breast cancer tissues positive for HPV type 6 and $88.2 \%$ were positive for HPV type 11.

Conclusion: The presence of human papillomavirus DNA in most breast carcinoma samples merits further investigation and confirmation by second assay in order to establish the exact role of this virus in the pathogenesis of breast cancer.

Keywords: Breast cancer, human papilloma virus type 6 and type 11, In situ hybridization technique.
\end{abstract}

\section{Introduction}

Breast cancer is one of the common malignancies among women worldwide (1). Breast cancer incidence rates varied internationally. The factors that participate to the international variation in incidence rates include differences in reproductive, hormonal factors and the availability of early detection services (1). The incidence has grown rapidly during the last decades in many developing countries and slowly in developed countries (2). In Iraq according to the 2012 Iraqi Cancer board report , breast cancer ranked the first among the commonest ten leading cancers in females in 2010 (3). There are well-known risk factors associated with the development of breast cancer including family history, hormones, smoking and alcohol consumption. However, in $50 \%$ to $80 \%$ of cases, the known risk factors are not identified which led to the attempt to identify new factors related with breast cancer (4). Recently viral infections have been implicated in the etiology of human breast cancer (5). The three most studied viruses that could possibly cause breast cancer in humans are: MMTV (mouse

*Dept.of cancer research/Iraqi Center for Cancer and Medical Genetics Research,/Al-Mustansiriyah University.

**Dept.of experimental therapy/Iraqi Center for Cancer and Medical Genetics Research,/Al-Mustansiriyah University.

*** Dept. of pathology / college of medicine / Al-Mustansiriyah University.

Email:noor.hashim@iccmgr.org mammary tumor virus / the onco RNA virus, MMTV or Bittner virus, the Epstein-Barr (EBV or gamma herpes virus), and the human papilloma (HPV) (6).Human papillomaviruses (HPV) are common viruses, they are small double stranded DNA viruses that infect mucosae and cutaneous surfaces and cause a variety of lesions ranging from common warts to cervical neoplasia and cancer (7). Human papillomaviruses (HPVs) genomes are less than 8,000 base pairs that encode approximately eight genes and require the host cell DNA replication machinery for their viral DNA replication (8). Their genomes can be separated into two coding regions early (E) and late (L), and a non-coding regulatory region (NCR) also referred to as Long Control Region (LCR) or Upstream Regulatory Region (URR) (8).There are approximately 200 types of HPV which are clinically classified as either low-risk or high-risk depending on the relative propensity of the HPVassociated lesions to undergo malignant progression (8). The suspicious role of HPV in human breast cancer is based on the identification of HPV of high oncogenic risk $(16,18,31,33$, and 35) in breast cancer tissues and in the immortalization of the human breast normal cells. The possible involvement of HPV in the etiology of breast cancer is controversial due to the difficulty to find the virus in the specimens, contrasting with the facility for detecting in cervical cancer (9).The aim of the present study was to investigate the presence of HPV type -6 
and HPV type -11 in a group of breast cancer tissue specimens from Iraqi female patients.

\section{Patients and Methods :}

Tissue samples, sectioning and slide preparation:

Thirty four formalin-fixed, paraffin embedded tissue blocks from breast cancer patients were obtained from the archive of the Pathology laboratory of Al-Yarmouk Teaching Hospital from January 2011 to July 2012 . The diagnosis of these tissue blocks were primarily based on their accompanied records. The patients age included in this retrospective study ranged from 26 to 65 years. In addition formalin-fixed, paraffin embedded tissue blocks from twenty fibroadenoma of breast were collected and used as control group with an age matched to the patients. Each formalin-fixed paraffin-embedded tissue block from breast cancer and fibroadenoma of breast was subjected to cut as serial thin sections of $(4 \mu \mathrm{m})$ thickness and were sticked on positive charge slides to be used for In situ hybridization for the detection of HPV type -6, -11. Ethical approval for use of all specimens was obtained and a confirmatory histopathological re-examination of each obtained tissue blocks was done by review of hematoxylin and eosin stained slides.

In situ hybridization procedure:

The method of In situ hybridization was conducted in accordance with manufacturer's instruction (Maxim Biotech, Inc., USA) in histopathology laboratory /cancer research department at Iraqi center for cancer and medical genetic research / Al-Mustansiriya University. For in situ hybridization technique (ISH), DNA Probe Hybridization/ Detection System in situ kit (Maxim Biotech, Inc., USA, cat \# IH-60001(IH-0050), high sensitivity type) was used .The probes were biotinylated long DNA probe for HPV type 6 (263bp.) (Maxim Biotech, Inc., USA, cat \# IH-60056) and HPV type 11(144bp.) (Maxim Biotech, Inc., USA, cat \# IH60057) . Briefly, slides were baked at $60 \mathrm{C}^{\circ}$ in oven overnight, deparaffinized in xylene and graded alcohols. The tissue was digested with $1 \mathrm{X}$ proteinase $\mathrm{k}$ solution for $15 \mathrm{~min}$ at $37^{\circ} \mathrm{C}$. After application of the biotinylated long DNA probe/ hybridization solution for HPV- 6 and HPV-11 was placed on each specified slides, hybridization solutions was placed on the tissue section and placed in the oven at $95^{\circ} \mathrm{C}$ for 10 minutes to denature the double stranded DNA followed by overnight incubation at $37 \mathrm{C}^{\circ}$ using moisturized chamber. Post-hybridization wash was performed the next day, followed by detection using the DNA Probe Hybridization/Detection System in situ kit. Proper use of this hybridization/detection System yields an intense blue- black signal appears at the specific site of the hybridized probe.

Scoring:

The in situ hybridization signal was evaluated by the counting of the number of the positive cells in the tissue that has given a blue-black (BCIP/NBT) staining under the light microscope. The score was the mean of 10 distinct high-power fields observed under $\times 100$ magnification. The percentage of positively stained cells was calculated for each case by taking the mean of the percentages of the positively stained cells in the 10 fields. Percentage score were assigned as following categories : score $0=0 \%$, score 1 (low $)=1-25 \%$, score 2( intermediate $)=26-50 \%$ and score 3 ( high $)=>50 \%$ (10) .

Statistical analysis:

Statistical analysis was done using Chi-Square test for statistical examination of all results obtained in our research. Values were considered statistically significant when $\mathrm{p}<0.05$.

\section{Results:}

Histopathological classification:

The patients' age included in this retrospective study ranged from 26 to 65 years. of these patients , 29 ( 85.3\% ) were infiltrative ductal carcinoma , $4(11.8 \%)$ were infiltrative lobular carcinoma and 1 ( $2.9 \%$ ) was infiltrative mammary carcinoma. Histological grading was as follow : 5 (14.7\%) were of well differentiated ( grade I ), 24 ( $70.6 \%$ ) were of moderately differentiated ( grade II ) and 5 ( $14.7 \%$ ) were of poorly differentiated (grade III) .

In situ hybridization detection of HPV type 6 and HPV type 11

The results of in situ hybridization detection of HPV type 6 and HPV type 11 are shown in table 1 , table 2 , figure 1 and figure 2 which were demonstrated that HPV type 6 was detected in $82.4 \%$ (28 out of 34 ) of the breast cancer samples .

Table1. Percentage of ISH detection of HPV type 6 DNA among study group.

\begin{tabular}{cccccc}
\hline \multirow{2}{*}{ Group } & No. & \multicolumn{2}{c}{$\begin{array}{c}\text { State of ISH } \\
\text { N(\%) }\end{array}$} & \multicolumn{2}{c}{$\begin{array}{c}\text { Comparison of } \\
\text { Significance }\end{array}$} \\
\cline { 3 - 5 } & & Positive & Negative & p-value & Significance \\
\hline Breast cancer & 34 & $28(82.4)$ & $6(17.6)$ & & \\
\hline $\begin{array}{c}\text { Fibroadenoma } \\
\text { of breast }\end{array}$ & 20 & $8(40)$ & $12(60)$ & & $\begin{array}{c}\text { significant } \\
(\mathbf{p}<0.01)\end{array}$ \\
\hline
\end{tabular}

Table2. Percentage of ISH detection of HPV type 11 DNA among study group.

\begin{tabular}{|c|c|c|c|c|c|}
\hline \multirow{2}{*}{ Group } & \multirow{2}{*}{ No. } & \multicolumn{2}{|c|}{$\begin{array}{l}\text { State of ISH } \\
\qquad \mathbf{N}(\%)\end{array}$} & \multicolumn{2}{|c|}{$\begin{array}{l}\text { Comparison of } \\
\text { Significance }\end{array}$} \\
\hline & & Positive & Negative & p-value & Significance \\
\hline Breast cancer & 34 & $30(88.2)$ & $4(11.8)$ & \multirow{2}{*}{0.002} & \multirow{2}{*}{$\begin{array}{c}\text { Significant } \\
(p<0.01)\end{array}$} \\
\hline $\begin{array}{c}\text { Fibroadenoma } \\
\text { of breast }\end{array}$ & 20 & $10(50)$ & $10(50)$ & & \\
\hline
\end{tabular}




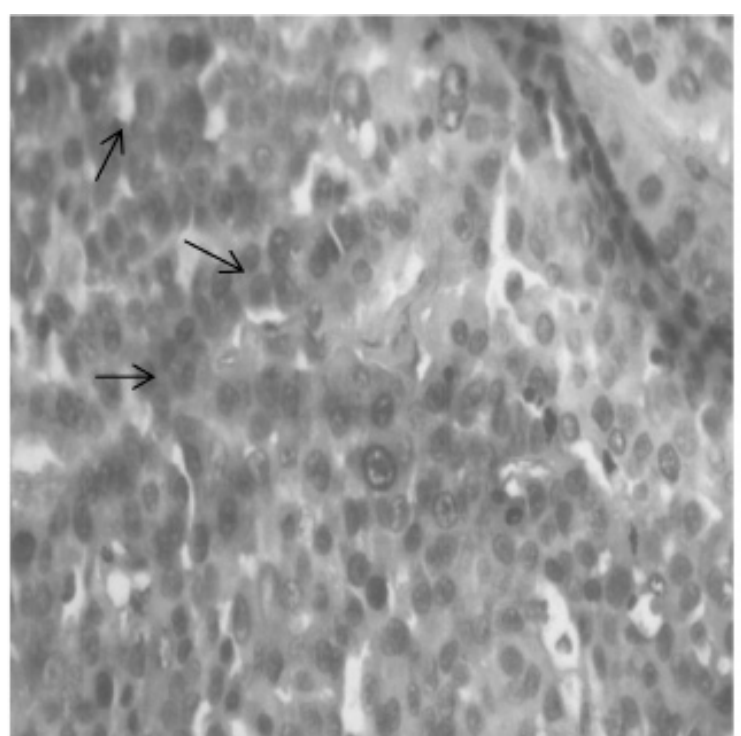

(a)

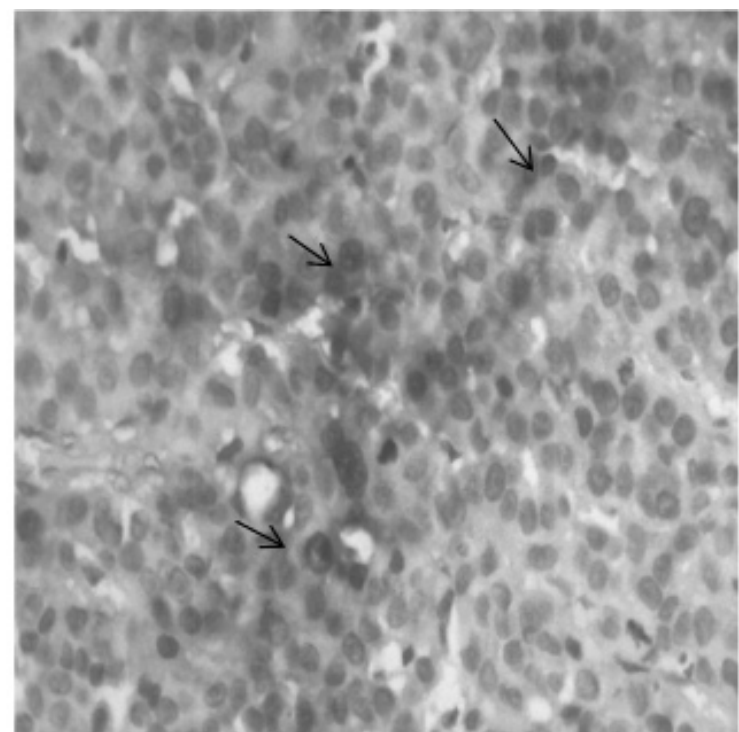

(b)

Fig.1 Infiltrative ductal carcinoma of breast showing positive ISH reaction for HPV type 6 (a) and HPV type 11 (b) using BCIP/NBT substrate/chromogen and counter stained by Hematoxyline (40x) .

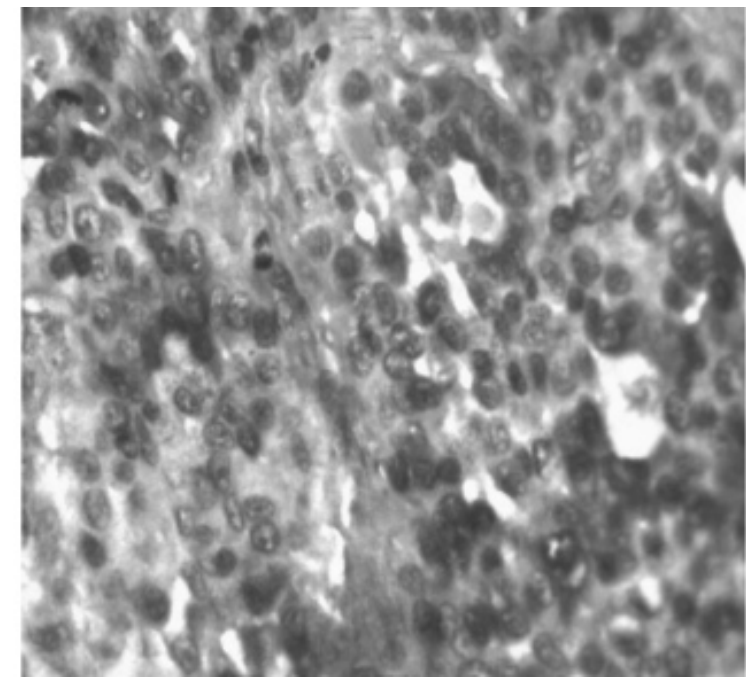

(a)

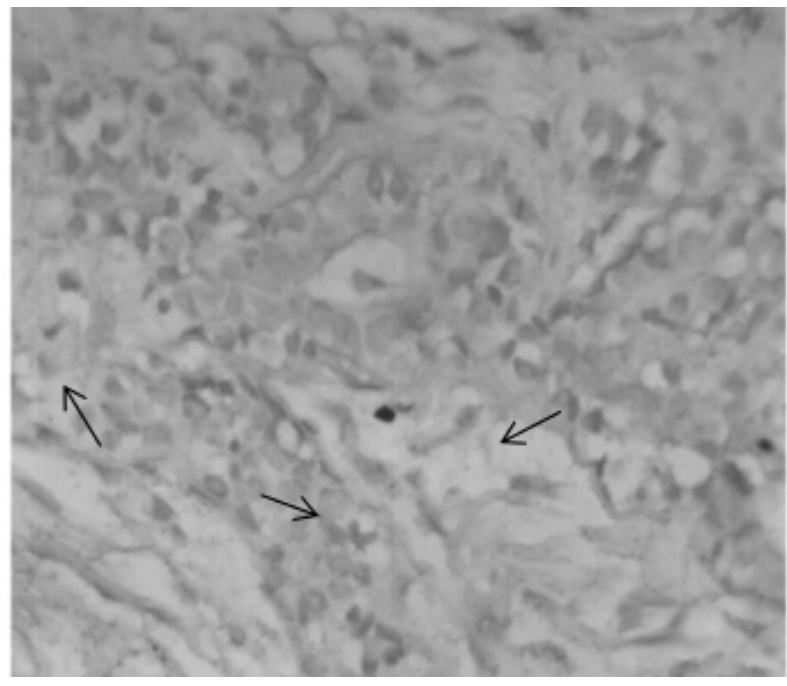

(b)

Fig.2 ISH reaction for HPV in fibroadenoma of breast, using BCIP/NBT substrate/chromogen and counter stained by Hematoxyline $(40 x)$. showing (a) positive ISH reaction ( HPV type 6) (b) Negative ISH reaction with fibroadenoma of breast.

HPV type 11 was detected in $88.2 \%$ (30 out of 34 ) of the breast cancer samples. Statistical analysis demonstrated significant differences in HPV type 6 and HPV type 11-positive ISH reactions among patients with breast cancer when compared with fibroadenoma of breast patients (control group). The simultaneous presence of both HPV types $(6+11)$ was detected in $70.6 \%$ ( 24 out of 34 ) of the breast cancer samples.A significant difference was found on comparing the percentages of HPV type 6 DNA among the study group (Table 3 ). 
Table3. Frequency distribution of in situ hybridization for HPV type 6 according to signal score among study group.

\begin{tabular}{|c|c|c|c|c|c|c|}
\hline \multirow{2}{*}{ Group } & \multicolumn{4}{|c|}{$\begin{array}{c}\text { ISH score for HPV type } 6 \\
\text { N(\%) }\end{array}$} & \multicolumn{2}{|c|}{ Comparison of significance } \\
\hline & Score 0 & Score 1 & Score 2 & Score 3 & p-value & Significance \\
\hline Breast cancer & $6(17.7)$ & $1(2.9)$ & $7(20.6)$ & $20(58.8)$ & \multirow{2}{*}{0.000} & \multirow{2}{*}{$\begin{array}{l}\text { Significant } \\
(\mathbf{p}<0.01)\end{array}$} \\
\hline Fibroadenoma of breast & $12(60)$ & $2(10)$ & $6(30)$ & $\mathbf{0}(0)$ & & \\
\hline
\end{tabular}

Table4. Frequency distribution of in situ hybridization for HPV type 11 according to signal score among study group .

\begin{tabular}{|c|c|c|c|c|c|c|}
\hline \multirow{2}{*}{ Group } & \multicolumn{4}{|c|}{$\begin{array}{l}\text { ISH score for HPV type } 11 \\
\text { N(\%) }\end{array}$} & \multicolumn{2}{|c|}{ Comparison of significance } \\
\hline & Score 0 & Score 1 & Score 2 & Score 3 & p-value & Significance \\
\hline Breast cancer & $4(11.8)$ & $3(8.8)$ & $7(20.6)$ & 20(58.8) & \multirow{2}{*}{0.000} & \multirow{2}{*}{$\begin{array}{l}\text { Significant } \\
(\mathbf{p}<0.01)\end{array}$} \\
\hline Fibroadenoma of breast & $10(50)$ & $4(20)$ & $6(30)$ & $\mathbf{0}(0)$ & & \\
\hline
\end{tabular}

HPV type 6 DNA high percentage was detected in $58.8 \%$ (20 out of 34) of breast cancer patients in high score (score 3) while in Fibroadenoma of breast group $60 \%$ (6 out of 10 ) were negative. As in HPV type 6 a significant difference was found on comparing HPV type 11 DNA among the study group according to score (Table 4).

High percentage of HPV type 11 DNA among breast cancer patients was found in high score 58.8\% (20 out of 34 ) and for Fibroadenoma of breast group 50\% (5 out of 10 ) were negative , 20\% ( 2 out of 10 ) were in low score (score 1) and $30 \%$ ( 3 out of 10 ) were in moderate score (score 2 ).

\section{Discussion:}

The results of our study showed that a significant differences in HPV type 6 and HPV type 11-positive ISH reactions among patients with breast cancer when compared with fibroadenoma of breast patients (control group). Significant differences were found on comparing HPV type 6 and HPV type 11 results according to score among study group. The controversial presence of HPV in breast cancer tissues have been evaluated by many studies. The prevalence of HPV in breast cancer tissue in a group of Iraqi patients is in consistent with previous publications reporting the presence of HPV in breast cancer in Iraq and world-wide (11-17). The differences in published studies concerning the types of HPV may be attributed to numbers of samples tested, methodological differences or the demographics of the samples tested. In contrast, several other studies failed to demonstrate HPV sequences in tumors of the breast (18-20). It is unclear whether these data truly represent the in vivo situation. It is well accepted that cancers of different human organ sites, other than cervical cancer harbor HPVDNA (21). The development of malignant tumors generally occurs after long latency periods during which additional cellular modifications happen within the infected cell (21). In HPV-associated carcinomas two viral oncoproteins, E6 and E7, are consistently expressed which contribute to tumor initiation and also play substantial role in malignant progression through the induction of genomic instability and other mechanisms (22). The E6 and E7 genes of the most prevalent high-risk HPV types, HPV 16 and HPV 18, modulate cellular pathways, thereby regulating proliferation and cell survival (20). In contrast, the E6 and E7 proteins of the low-risk types, HPV 6 and HPV 11, do not effect these cellular pathways in the same manner, although they have occasionally been demonstrated in premalignant and malignant tumors (23). Additional cofactors are probably needed to modulate cellular proteins so as to immortalize and transform the infected cells (23). However, preliminary data indicate that several molecular pathways are probably followed depending on the HPV type involved (24). The data demonstrate the occurrence of HPV type 6 and 11 DNA in high percentage, $82.4 \%$ and $88.2 \%$ respectively in breast cancer tissues. We detected the simultaneous presence of both HPV types $(6+11)$ in $70.6 \%$ ( 24 out of 34$)$ of the breast cancer samples. 


\section{Conclusion:}

The presence of human papillomavirus DNA in most breast carcinoma samples merits further investigation and larger numbers of cases need to be analyzed in order to establish the exact role of this virus in the pathogenesis of breast cancer. Furthermore, another confirmatory assay should be applieed on the same sample to confirm the results such as using polymerase chain reaction (PCR) technique or immunohistochemistry. Identifying the presence of human papillomavirus might aid early diagnosis, prevention and perhaps therapy.

\section{Authors Contributions:}

Noor H. Ismail: study conception, design, practical part of ISH, acquisition of data analysis, interpretation of data ,critical revision and drafting of manuscript.

Ahmed M. Al-Shammeri : study conception , design interpretation of data and critical revision.

Ayser H. Latif ,: interpretation of data, histopathological examination and critical revision.

\section{References:}

1- Jemal A, Bray F and Center MM. Global Cancer Statistics. Cancer J Clin . (2011) ; 61:69-90.

2-Boyle $P$ and Levin B. World Cancer Report 2008. International Agency for Research on Cancer. France. (2008) ; pp: 12-43.

3- Ministry of Health, Iraqi Cancer Board (2012). Results of Iraqi Cancer Registry 2010.

4- Hortobagyi GN, De la Garza Salazar J, Pritchard K, Amadori D, Haidinger $R$, Hudis $C A$, et al. The globalbreast cancer burden: variations in epidemiology and survival.Clin Breast Cancer.(2005); 6:391-401.

5- Lawson JS and Benjamin H. Viruses and Breast Cancer. Cancers.(2010), 2: 752-772.

6- Lawson JS, Tran D and Rawlinson WD. From Bittner to Barr: a viral, diet and hormone breast cancer aetiology hypothesis. Breast Cancer Res. (2001); 3:81-85.

7- Yim E-K and Park J-S. Biomarkers in Cervical Cancer. Biomark Insights. (2006); 1: 215-225.

8-McLaughlin-Drubin $M$ E and Münger K. Oncogenic Activities of Human Papillomaviruses. Virus Res. (2009); 143: 195-208.

9- Khan NA, Castillo A, Koriyama C, Kijima Y, Umekita Y, Ohi Y, et al. Human papillomavirus detected in female breast carcinomas in Japan. Br J Cancer. (2008); 99: 408-414.

10- Blancato J, Singh B, Liu A, Liao D and Dickson $R$. Correlation of amplification and overexpression of the c-myc oncogene in high-grade breast cancer: FISH, in situ hybridization and immunohistochemical analysis. Br J Canc . (2004); 90: 1612-1619.

11- AL-Mansour AA, AL-Obaidy SR and AL-Ouqaili MTS.
Detection of Human Papilloma Virus in Iraqi Patients with Breast Cancer. The Iraqi Postgraduate Medical Journal. (2012); 11:471-478.

12- Ali SHM, Al-Alwan NAS and Al-Alwany SHM . Detection and genotyping of human papillomavirus in breast cancer tissues from Iraqi patients. EMHJ. (2014);20:372-377.

13- AkilN, Yasmeen A, Kassab A, Ghabreau L, Darnel AD and Al Moustafa A-E. High-risk human papillomavirus infections in breast cancer in Syrian women and their association with Id-1 expression: a tissue microarray study. Br J Canc. (2008); 99:404-407.

14- de Villiers EM, Sandstrom R E, zur Hausen H and Buck CE. Presence of papillomavirus sequences in condylomatous lesions of the mamillae and in invasive carcinoma of the breast. Breast Cancer Res.(2005); 7:R1-R11.

15- de León DC, Montiel DP, Nemcova J, Mykyskova, I, Turcios E, Villavicencio $V$, et al.Human Papillomavirus (HPV) in breast tumors: prevalence in a group of Mexican patients. BMC Cancer. (2009); 9:26.

16- Glenn WK, Heng B, Delprado W, Iacopetta B, Whitaker NJ and Lawson JS. Epstein-Barr Virus, Human Papillomavirus and Mouse Mammary Tumour Virus as Multiple Viruses in Breast Cancer. PLOS ONE. (2012); 7: e48788.

17- Divani SN and Giovani AM. Detection of human papillomavirus DNA in fine needle aspirates of women with breast cancer. Arch Oncol. (2012); 20:12-14.

18- Hedau S, Kumar U, Hussain S, Shukla S, Pande S, Jain $N$, et al. Breast cancer and human papillomavirus infection: No evidence of HPV etiology of breast cancer in Indian women BMC Cancer. (2011);11:27.

19- Silva Jr. RG. and da Silva BB. No evidence for an association of human papillomavirus and breast carcinoma . Breast Cancer Res Treat . (2011);125:261-264.

20- Gopalkrishna V, Singh UR, Sodhani P, Sharma JK, Hedau ST, Mandal AK, et al. Absence of human papillomavirus DNA in breast cancer as revealed by polymerase chain reaction. Breast Cancer Res Treat .(1996); 39:197-202.

21- Mammas IN, Sourvinos G, Zaravinos A and Spandidos DA. Vaccination against Human Papilloma Virus (HPV): Epidemiological Evidence of HPV in Non-genital Cancers. Pathol. Oncol. Res. (2011); 17:103-119.

22- Howie HL, Katzenellenbogen RA and Galloway DA. Papillomavirus E6 proteins. Virology. (2009) ; 384: 324-334. (IVSL)

23- Klingelhutz AJ and Roman A. Cellular transformation by human papillomaviruses: Lessons learned by comparing highand low-risk viruses. Virology.(2012) ; 424: 77-98. (IVSL)

24- Ganguly $N$ and Parihar SP. Human papillomavirus E6 and E7 oncoproteins as risk factors for tumorigenesis. J. Biosci.(2009); 34: 113-123. 